\title{
Erythrocyte Adenosine Deaminase Deficiency without Immunodeficiency
}

\author{
EVIDENCE FOR AN UNSTABLE MUTANT ENZYME
}

\begin{abstract}
Rochelle Hirschhorn, Vivien Roegner, Trefor Jenkins, Carol Seaman, Sergio Piomelli, and William Borkowsky, Departments of Medicine and Pediatrics, New York University School of Medicine, New York 10016, Department of Human Genetics, School of Pathology, The South African Institute for Medical Research, University of the Witwatersrand, Johannesburg, South Africa
\end{abstract}

A B S TRACT Inherited deficiency of the purine salvage enzyme adenosine deaminase (ADA) gives rise to a syndrome of severe combined immunodeficiency (SCID). We have studied a 2.5-yr-old immunologically normal child who had been found to lack ADA in his erythrocytes during New York State screening of normal newborns. His erythrocytes were not detectably less deficient in ADA than erythrocytes of $\mathrm{ADA}^{-}$SCID patients. In contrast, his lymphocytes and cultured long-term lymphoid cells contained appreciably greater ADA activity than those from patients with ADA $^{-}$-SCID. This residual ADA activity had a normal molecular weight and $K_{\mathrm{m}}$ but was markedly unstable at $56^{\circ} \mathrm{C}$. His residual erythrocytes-ADA activity also appeared to have diminished stability in vivo. ADA activity in lymphoid line cells of a previously reported erythrocyte-ADA-deficient!Kung tribesman was found to contain $50 \%$ of normal activity and to exhibit diminished stability at $56^{\circ} \mathrm{C}$. ATP content of erythrocytes from both partially ADA-deficient individuals was detectably greater than normal (12.3 and 6.1 vs. normal of $2.6 \mathrm{nmol} / \mathrm{ml}$ packed erythrocytes). However, the dATP content was insignificant compared to that found in erythrocytes of $\mathrm{ADA}^{-}$-SCID patients (400$1,000 \mathrm{nmol} / \mathrm{ml}$ packed erythrocytes). The New York patient, in contrast to normals, excreted detectable amounts of deoxyadenosine, but this was $<2 \%$ of deoxyadenosine excreted by ADA $^{-}$-SCID patients. Thus, the residual enzyme in cells other than erythrocytes appears to be sufficient to almost totally prevent accumulation of toxic metabolites.

W. Borkowsky is supported by U. S. Public Health Service training grant 5T01AI00005-20.

Received for publication 7 February 1.97 .9 and in revised form 29 May 1979.

\section{INTRODUCTION}

Inherited deficiency of adenosine deaminase (ADA), ${ }^{1}$ an enzyme of purine salvage, usually results in the syndrome of severe combined immunodeficiency disease (SCID) (1-3). Approximately $85 \%$ of ADAdeficient infants present with full blown, classic SCID. In these patients, cellular and humoral immune function are both profoundly impaired, their illness begins during the first few months of life, and they succumb rapidly to their multiple infections. Approximately $15 \%$ of ADA-deficient infants become ill at a later age and have a more prolonged course, although they too eventually succumb to their disease within the first few years of life. In vitro tests of immune function in these latter patients reveal a more pronounced defect of cellular than of humoral immunity $(2,3)$. This clinical heterogeneity could result from either genetic heterogeneity or random differences in exposure to infectious agents. Genetic heterogeneity alone would appear to account for the one clinically healthy, immunologically normal individual who was inadvertently discovered during population studies of the !Kung tribe of the Kalahari Desert (4). This !Kung tribesman lacks ADA in his erythrocytes but his lymphocytes contain appreciable ADA activity (5). Extensive prior studies of many different populations, directed at determining frequencies of the genetically polymorphic forms of ADA, had not detected any other healthy individual deficient for ADA (6). As part of the New York State mandatory screening of newborns, a second individual who totally lacks ADA in his erythro-

${ }^{1}$ Abbreviations used in this paper: ADA, adenosine deaminase; EHNA, erythro-9-(2-hydroxy-3-nonyl-) adenine; LTL, long-term lymphoid RBC, erythrocyte(s); SCID, severe combined immunodeficiency disease. 
cytes but who has remained clinically healthy and immunologically normal at $2.5 \mathrm{yr}$ of age $(7)^{2}$ has been ascertained. We have quantitatively and qualitatively examined ADA activity in this child's erythrocytes and lymphoid cells, both cultured and uncultured. We have compared this child's ADA activity with that found in cells of patients with ADA deficiency and SCID and in cells of the previously reported healthy !Kung tribesman. We have also compared adenosine and deoxyadenosine metabolites in cells and body fluids. The lymphocytes and cultured lymphoid line cells of our patient, similar to the !Kung tribesman, have greater residual activity than do those of other ADA-deficient patients who are immunodeficient, but this adenosine deaminating activity is unstable in vitro, as is the ADA of the !Kung tribesman. However, this ADA activity is sufficient in both our patient and the !Kung tribesman to almost totally prevent the accumulation of substrates of ADA and their potentially toxic metabolites in vivo.

\section{METHODS}

Nucleosides and nucleotides were obtained from Sigma Chemical Company, (St. Louis, Mo.) and/or P-L Biochemicals, Inc. (Milwaukee, Wis.). $\left[8-{ }^{14} \mathrm{C}\right]$ Adenosine $(\cong 50 \mu \mathrm{Ci} / \mu \mathrm{M})$ was purchased from Schwarz/Mann Div., Becton, Dickinson \& Co. (Orangeburg, N. Y.) and $\left[8-{ }^{14} \mathrm{C}\right]$ deoxyadenosine $(\cong \mathbf{4 4}$ $\mu \mathrm{Ci} / \mu \mathrm{M})$ from New England Nuclear (Boston, Mass.), nucleoside phosphorylase and xanthine oxidase from Boehringer Mannheim Biochemicals (Indianapolis, Ind.) Erythro9-(2-hydroxy-3-nonyl) (EHNA) was obtained from Burroughs Wellcome Co. (Research Triangle Park, N. C.), Escherichia coli DNA polymerase (catalogue L500-06316) from Worthington Biochemicals (Freehold, N. J.), and calf thymus DNA from Sigma Chemical Co.

\section{Adenosine and deoxyadenosine deaminating activity.}

Method 1 ("high substrate"). Adenosine and deoxyadenosine deaminating activity were assayed as previously described (8) by a modification of the method of Hopkinson (9) in which the substrate concentration is approximately four times that originally used. This method measures the increase in absorbance at $293 \mathrm{~nm}$ resulting from the conversion of adenosine to inosine by endogenous ADA and then to uric acid by the sequential action of exogenous nucleoside phosphorylase and xanthine oxidase at $37^{\circ} \mathrm{C}$. In brief, a reaction mixture was made with $1.3 \mathrm{mM}$ adenosine or deoxyadenosine in $0.05 \mathrm{M} \mathrm{Na} / \mathrm{PO}_{4}$ buffer, $\mathrm{pH} 7.5,1 \mu \mathrm{g} / \mathrm{ml}$ nucleoside phosphorylase, and $50 \mu \mathrm{g} / \mathrm{ml}$ xanthine oxidase. Aliquots of cell suspension $(0.1 \mathrm{ml}$ of a $1: 41$ dilution of washed erythrocyte(s) (RBC) or from 25 to $500 \mu \mathrm{g}$ of lymphocyte or lymphoid line cell lysate protein) were added per milliliter of reaction mix and the rate of increase in absorbance at $293 \mathrm{~nm}$ determined for a linear portion of the curve. The rate of reaction was linear with varying protein concentration for the aliquots used. For assay of RBC the endogenous nucleoside phosphorylase

\footnotetext{
${ }^{2}$ Borkowsky, W., A. A. Gershon, L. Shenkman, and R. Hirschhorn. Adenosine deaminase deficiency without immunodeficiency: clinical and metabolic studies. Manuscript submitted for publication.
}

is not rate limiting, and exogenous nucleoside phosphorylase was therefore omitted. The activity of a reagent blank, minus cell extract, was determined simultaneously, to correct for the ADA contaminating the commercial exogenous enzyme preparations.

Method 2("low substrate"). To increase the specificity of the ADA assay, enzyme activity was determined at low substrate concentration and as that activity which could be inhibited by $50 \mu \mathrm{M}$ EHNA, an inhibitor of ADA. Such assay conditions should eliminate measurement of the activity of a second isozyme of $\mathrm{ADA}\left(\mathrm{ADA}_{2}\right)$ which is present in normal amounts in $\mathrm{ADA}_{1}{ }^{-}$-SCID patients, is active at high substrate concentrations, and is not inhibitable by EHNA (10). Additionally, the assays were performed in tris EDTA buffer to inhibit possible formation of inosine by sequential phosphorylation, deamination, and dephosphorylation of adenosine through alternative pathways. On a kinetic basis alone, enzyme activity determined at $0.09 \mathrm{mM}$ substrate concentration should be $\cong 70 \%$ of that seen at $1.3 \mathrm{mM}$ substrate, calculating from a $K_{m}$ of $40 \mu \mathrm{M}$. The conversion of $\left[{ }^{14} \mathrm{C}\right]$ adenosine or deoxyadenosine to inosine or deoxyinosine (and hypoxanthine) was measured essentially by minor modifications of the method of Coleman (11). In brief, lysates were incubated at $37^{\circ} \mathrm{C}$ with $0.09 \mathrm{mM}\left[{ }^{14} \mathrm{C}\right.$ ]adenosine (Schwarz/ Mann, $\cong 50 \mu \mathrm{Ci} / \mu \mathrm{mol}$ ) or deoxyadenosine (New England Nuclear, $\cong 44 \mu \mathrm{Ci} / \mu \mathrm{mol}$ ) in $24 \mathrm{mM}$ Tris, $2.4 \mathrm{mM}$ EDTA buffer, $\mathrm{pH} 7.5$, in the presence and absence of $50 \mu \mathrm{M}$ EHNA. The reaction was terminated at intervals between 30 and $120 \mathrm{~min}$ by addition of $10 \mu \mathrm{l}$ of $2.1 \mathrm{~N}$ perchloric acid to $50-\mu \mathrm{l}$ aliquots of the reaction mixture. After centrifugation and subsequent neutralization of the supernate with $10 \mu \mathrm{l}$ of $2.21 \mathrm{~N} \mathrm{KOH}, 20-\mu \mathrm{l}$ aliquots were cochromatographed with internal standards on DE 81 paper in $1 \mathrm{mM}$ ammonium formate. The relevant areas were identified under UV light, the entire chromatogram appropriately sectioned, and radioactivity of all sections determined. Adenosine and deoxyadenosine were widely separated from hypoxanthine, inosine, and deoxyinosine. Virtually no counts $(<0.1 \%)$ were found as nucleotides under these conditions of assay. Activity was calculated by determining the percentage of the total counts recovered which were present as hypoxanthine and inosine. Lysates were appropriately diluted to result in $5-30 \%$ conversion of substrate. Assays were performed at two or more time points and at two protein concentrations. Results reported are for values that are linear for protein concentration and time of assay.

Determination of ADA phenotype. The normal inherited polymorphic forms of $\mathrm{ADA}\left(\mathrm{ADA}_{1} \mathrm{l}_{1} \mathrm{ADA}_{1} 2\right.$, and $\mathrm{ADA}_{1} 2-1$ ) were determined by electrophoresis in starch gel as described by Spencer et al. (12).

Heat stability. Cell pellets were resuspended in $0.15 \mathrm{M}$ $\mathrm{NaCl}, 0.05 \mathrm{M}$ Tris, $\mathrm{pH} 7.5$, at a protein concentration of $>1$ $\mathrm{mg} / \mathrm{ml}$, to avoid effects of ionic strength and protein on heat stability $(13,14)$. The ADA phenotype of all normal lymphoid cells used in heat stability experiments, unless otherwise noted, was ADA 1, as normal $\mathrm{ADA}_{1} 2-1$ is slightly less stable than $\operatorname{ADA}_{1} 1(13,14)$. Equal volumes of cell lysate at equal protein concentrations were incubated for the indicated time intervals at $56^{\circ} \mathrm{C}$. After removal to ice, the lysates were appropriately diluted so that assay of the zero time sample would result in $\cong 10-30 \%$ conversion of the $\left[{ }^{14} \mathrm{C}\right]$ adenosine and would be equivalent in the lysates to be compared. Two dilutions were assayed at each time point in the presence and absence of EHNA.

Sephadex G-200 chromatography. Chromatography of cell lysates was performed on $0.6 \times 30-\mathrm{cm}$ Sephadex G-200 columns (Pharmacia Fine Chemicals Inc., Piscataway, N. J.) which had been calibrated with nucleoside phosphorylase 
$(89,000)$, peptidase B $(54,000)$ and ADA $(32,000)$. Lysates of $20 \times 10^{6}$ cells were centrifuged in a Beckman microfuge (Beckman Instruments, Inc., Fullerton, Calif.) for $3 \mathrm{~min}$, applied to the column, and eluted with $0.025 \mathrm{M}$ Tris, 2.25 $\mathrm{mM}$ EDTA, pH 7.5, at a flow of $1.7 \mathrm{ml} / \mathrm{h}$. Fractions of $0.25 \mathrm{ml}$ were collected and assayed as described under "low substrate."

$K_{\mathrm{m}}$. ADA activity of two concentrations of lysates at various substrate concentrations was measured and $K_{\mathrm{m}}$ determined by standard Lineweaver-Burk plots. $K_{\mathrm{m}} \mathrm{s}$ were determined after assay both by the high substrate method and by appropriate dilutions of $\left[{ }^{14} \mathrm{C}\right]$ adenosine with or without added unlabeled adenosine.

Source of long-term lymphoid cells. Long-term lymphoid lines were initiated from peripheral blood by the National Institutes of Health Human Genetic Mutant Cell Repository (Camden, N. J.), from patients of Dr. R. Hong (GM 2606) (15), Dr. A. Rubinstein (GM 2756) (15, 16), Dr. S. Polmar (GM 2471) $(8,15,17)$, Dr. T. Jenkins (GM 3043) $(4,5,18)$, Dr. J. Lightbody (GM 1715) (19), Dr. P. Papageorgiou (GM 2825), and from the patient reported here (GM 2294) $(7,15)$. Cells from patients of Dr. R. Hong (15) and Dr. C. Griscelli were also studied but long-term lymphoids (LTL) are not available. A series of genetically polymorphic enzyme markers was determined at intervals to confirm the identity of the lines under study.

The clinical and immunological studies of the 2.5-yr-old immunologically normal child studied here have been previously reported (7) and other than transient hypogammaglobulinemia at $6 \mathrm{mo}$, no abnormalities of cellular and humoral immunity in vivo or in vitro have been detected.

Preparation of cell extracts. RBC were washed three times with the removal of the buffy coat and packed cells diluted 1:41 in $0.001 \mathrm{M} \mathrm{PO}_{4}$ or in $0.001 \mathrm{M}$ Tris for some assays at low substrate. Deficient RBC were diluted 1:5 or 1:10 for assays with radiolabeled compounds. RBC of the RBC-ADAdeficient healthy patient and the !Kung tribesman were separated from lymphocytes on Hypaque-Ficoll (Radiopaque Media, Winthrop Laboratories, New York, N. Y.) and then washed three times with further removal of the remaining buffy coat.

Lymphoid cells were suspended in $0.001 \mathrm{M}$ Tris, $\mathrm{pH} 7.5$, at such concentrations that the Tris did not affect the Lowry determinations, frozen and thawed five times, and briefly sonicated. Aliquots were then appropriately diluted for assay.

Deoxy and adenosine kinase. These activities were assayed as described by Carson (20), except that the final concentration of deoxyadenosine was $0.246 \mathrm{mM}$, adenosine $103 \mathrm{mM}$, ATP $4.4 \mathrm{mM}$, and $\mathrm{MgCl}_{2} 2.2 \mathrm{mM}$.

dATP. dATP in RBC was determined by high-pressure liquid chromatography on a Laboratory Data Control System with a variable UV monitor using a Whatman Partisil 10 SAX column (Whatman, Inc., Clifton, N. J.) as described by Cohen (15) and by the more sensitive DNA polymerase assay adapted from Solter et al. (21). Essentially, 10- $\mu$ l aliquots of perchloric acid precipitated, $\mathrm{KOH}$-neutralized extracts were incubated in the presence of saturating concentrations of unlabeled dCTP, dTTP and dGTP, and $\left[\mathrm{U}_{-14}{ }^{14} \mathrm{C}\right] \mathrm{dCTP}$ (Amersham Corp., Arlington Heights, Ill., $414 \mathrm{mCi} / \mathrm{mmol}$ ) using a template of calf thymus DNA and E. coli DNA polymerase (Worthington Biochemicals). The assay was linear between 25 and 1,000 $\mathrm{pmol} / 10-\mu \mathrm{l}$ sample.

Deoxyadenosine and adenosine. Deoxyadenosine and adenosine in urine were determined both with and without prior separation on anion exchange columns (AG 1-X2, BioRad Laboratories, Richmond, Calif.) essentially as described by Kuttesch et al. (22), and fractions lyophilized. The urinary nucleosides were separated by high-pressure liquid chroma- tography on a Waters ${ }^{18} \mathrm{C}$ Bondapak reverse phase column (Waters Associates, Milford, Mass.) by a modification of the method of Brown (23) using a flow rate of $1.5 \mathrm{ml} / \mathrm{min}$ and a 30 -min linear gradient starting with $10 \mathrm{mM}$ ammonium phosphate buffer, pH 5.5, and ending with $20 \%$ methanol in the initial buffer. Adenosine and deoxyadenosine were identified by coelution with standards, $250: 260$ ratios, and peak shift to the elution volume of inosine and deoxyinosine following incubation with exogenous calf-intestinal ADA.

Separation of $R B C$ on discontinuous density gradients. Before centrifugation blood was either passed through filter paper or, in later experiments, through $\alpha$-cellulose-microcrystalline cellulose columns as described by Beutler (24) for removal of leukocytes. RBC of differing densities were then separated by centrifugation on arabinogalactan gradients as described (25). Gradient fractions were washed, and aliquots lysed for determination of pyruvate kinase activity and hemoglobin content. Aliquots for assay of ADA were lysed as above but were also lysed in $0.01 \mathrm{M} \mathrm{PO}_{4}, 0.001 \mathrm{M}$ EDTA, pH 7.5, in which lymphocytes remained intact, centrifuged and the supernate assayed for ADA.

\section{RESULTS}

ADA activity in RBC, lymphocytes, and LTL line cells. ADA activity of the child's RBC, determined at high substrate concentrations $(1.3 \mathrm{mM})$, was $<1 \%$ of normal, and indistinguishable from ADA activity in RBC of four ADA-deficient patients with SCID $\left(\mathrm{ADA}_{1}{ }^{-}\right.$-SCID) (Table I). (RBC-ADA activity of both his parents was below 2 SD from the normal.) ADA activity of his mononuclear cells, determined at high substrate concentrations, was $214 \pm 43 \mathrm{U}$ ( $17 \%$ of normal) compared with an average of $136 \pm 66 \mathrm{U}$ ( $10 \%$ of normal) in mononuclear cells from five $\mathrm{ADA}_{1}{ }^{-}$-SCID. Although average ADA activity in the RBC-ADAhealthy child's mononuclear cells appeared to be slightly higher than in mononuclear cells of the immunodeficient children ( $214 \mathrm{vs} .136 \mathrm{U})$, there was overlap of individual values between the two groups and the difference was not significant $(P>0.2)$. No such overlap was observed upon determination of ADA activity of cultured lymphoid line cells. ADA activity of LTL line cells derived from this patient was markedly greater than that observed in LTL of ADA- ${ }^{-}$SCID patients ( 590 vs. $13 \mathrm{U}$ ). Normal lymphoid line cells contained an average of 2,003 $\mathrm{U}$ (range, 1,200-2,700).

The relatively minor difference in ADA activity of peripheral blood mononuclear cells, but marked difference in ADA activity of LTL cells from our $\mathrm{ADA}^{-}$ healthy patient, as compared with that of patients with $\mathrm{ADA}^{-}$-SCID, led us to further investigate this adenosine deaminating activity. Schrader et al. (10) have described an additional ADA activity in some normal tissues which differs from the major ADA in that it is active only at high substrate concentrations, is not inhibitable by EHNA (an inhibitor of the usual form of ADA), and is found in normal amounts in tissues of an ADA-deficient child. In accordance with isozyme nomenclature we have tentatively denoted the high- 
TABLE I

ADA Activity* in RBC, Mononuclear Cells, and Lymphoid Line Cells at High (1.3 mM) Substrate

\begin{tabular}{|c|c|c|c|c|c|c|c|}
\hline \multirow[b]{2}{*}{$\mathrm{ADA}_{1}{ }^{-}$-healthy $(n) \ddagger$} & \multirow[t]{2}{*}{ Patient } & \multicolumn{2}{|c|}{$\mathrm{RBC}$} & \multicolumn{2}{|c|}{$\begin{array}{l}\text { Mononuclear } \\
\text { cells }\end{array}$} & \multirow{2}{*}{\multicolumn{2}{|c|}{$\begin{array}{c}\begin{array}{c}\text { Lymphoid } \\
\text { line cells }\end{array} \\
590.0 \pm 115.0(6)\end{array}$}} \\
\hline & & $0.4 \pm$ & $(3)$ & $214 \pm 43$ & $(5)$ & & \\
\hline \multirow{7}{*}{$\mathrm{ADA}_{1}{ }^{-}-\mathrm{SCID} \quad(n) \ddagger$} & 1 & - & & $119 \pm 11$ & (3) & 17.0 & $(2)$ \\
\hline & 2 & - & & 156 & (1) & 7.4 & (2) \\
\hline & 3 & 0.0 & (1) & - & & - & \\
\hline & 4 & 1.8 & (1) & 100 & $(2)$ & - & \\
\hline & 5 & - & & 67 & (2) & 6.7 & $(2)$ \\
\hline & 6 & 0.9 & (1) & 240 & (1) & $22.0 \pm 0.16$ & (4) \\
\hline & 7 & 0.91 & (1) & - & & - & \\
\hline Average & & $9.9 \pm$ & & $136 \pm 66$ & & $13.3 \pm 7.5$ & \\
\hline Normals & & $85.0 \pm$ & $0(77)^{\|}$ & $1,291 \pm 315$ & $(17)^{\prime \prime}$ & $2,003.0 \pm 641$. & $(5)^{\prime}$ \\
\hline
\end{tabular}

Patient $1=$ GM 2756; 2 = GM 2606; 3 = GM 2825; 4 = patient (R.J.) of Dr. R. Hong; $5=$ GM 2471; 6 = GM 1715; 7 = patient S of Dr. C. Griscelli (see Methods for further identification).

* Measured in nanomoles per milligram protein or hemoglobin per hour at $37^{\circ} \mathrm{C}$.

$\$$ Number of determinations.

$\S$ Patient transfused.

"Number of individuals tested.

affinity ADA which is deficient in $\mathrm{ADA}^{-}$-SCID and can be inhibited by EHNA as $\mathrm{ADA}_{1}$ and the lowaffinity ADA which is present in normal amounts in $\mathrm{ADA}^{-}$-SCID as $\mathrm{ADA}_{2}$. Because the residual ADA activity we had measured in cells from $\mathrm{ADA}^{-}$patients at high substrate could represent in whole or in part this additional $\mathrm{ADA}_{2}$ activity, we determined ADA activity under conditions designed to measure only the activity of $\mathrm{ADA}_{1}$. We therefore have determined activity at low substrate concentration and as EHNA-inhibitable activity. RBC both from our healthy patient and from three ADA $^{-}$patients with SCID contained $<0.1 \mathrm{U}$ EHNA-inhibitable ADA activity (Table II) compared to normal activity of $61 \mathrm{U}$. Under these conditions of assay, lymphocytes from six immunodeficient patients were also markedly deficient and contained an average of $12.4 \mathrm{U}$ EHNA-inhibitable ADA activity compared with normal activity of $665 \mathrm{U}$. In contrast, lymphocytes from the healthy patient still exhibited substantial EHNA-inhibitable ADA activity (157 U). Lymphocytes from the !Kung tribesman also contained more ADA activity $(45 \mathrm{U})$ than those of $\mathrm{ADA}^{-}$-SCID. (However, the activity of the !Kung lymphocytes and/or RBC may be factitiously low because the cells were in transit for almost $1 \mathrm{wk}$ before separation and assay.) ADA activity of cultured LTL line cells derived from five $\mathrm{ADA}^{-}$SCID patients showed a pattern similar to that of peripheral blood lymphocytes. LTL from $\mathrm{ADA}^{-}$-SCID were profoundly deficient in activity, with an average ADA activity of $5.4 \mathrm{U}$ compared with normal activity of 1,558. LTL line cells from our RBC-ADA ${ }^{-}$patient again exhibited substantial ADA activity $(227 \pm 150 \mathrm{U}$; range, $90-564)$. Lymphoid line cells derived from the !Kung tribesman contained an average of $887 \pm 291 \mathrm{U}$ (range, $524-1,306)$. ADA activity of lymphoid line cells from our $\mathrm{ADA}^{-}$healthy patient and from the !Kung tribesman showed much greater variability at different times than did that from individual normal lymphoid lines. It is of interest that the activity of lymphoid line cell extracts from patient 6 (GM 1715) was virtually undetectable only when determined at low substrate and as EHNA-inhibitable activity (Table I vs. Table II).

In theory, a mutation of the ADA enzyme molecule could affect adenosine deaminating activity relative to deoxyadenosine deaminating activity. Because accumulation of deoxyadenosine compounds appears to be implicated in the pathophysiology $(14,15,17,24)$ we determined deoxyadenosine deaminating activity. The ratio of deoxyadenosine to adenosine deaminating activity was essentially the same in our patient's lymphoid cells as in normals (Table III). In three of the four $\mathrm{ADA}^{-}$-SCID patients' cells tested, deoxyadenosine deaminating activity had a ratio of adenosine to deoxyadenosine deaminating activity similar to normal. In the cells of a fourth patient (GM 1715), the ratio of adenosine:deoxyadenosine deaminating activity appeared to be low. However, the absolute activities in these cells were extremely low and would require further investigation. Deoxyadenosine and adenosine phosphorylating activity was also similar in lymphoid cell extracts from normals, ADA- $^{-}$-SCID patients, and our partially $\mathrm{ADA}^{-}$patient (data not shown). 
TABLE II

ADA Activity, ${ }^{*}$ in RBC, Mononuclear Cells, and Lymphoid Line Cells at Low (0.09 mM) Substrate

\begin{tabular}{|c|c|c|c|c|c|c|}
\hline \multirow{3}{*}{$\begin{array}{l}\operatorname{ADA}_{1}{ }^{-} \text {-healthy }(n) \downarrow \\
\operatorname{ADA}_{1}{ }^{-}-\text {Kung } \quad(n) \downarrow\end{array}$} & \multirow[t]{2}{*}{ Patient } & & & \multicolumn{2}{|c|}{$\begin{array}{c}\text { Mononuclear } \\
\text { cells }\end{array}$} & \multirow{2}{*}{$\begin{array}{c}\text { Lymphoid } \\
\text { line cells }\end{array}$} \\
\hline & & \multicolumn{2}{|c|}{$0.05 \pm 0.02$} & 156.9 & $(2)$ & \\
\hline & & $0.13 \S$ & (1) & $44.9 \S$ & (1) & $887.0 \pm 291.0(6)$ \\
\hline \multirow[t]{7}{*}{$\mathrm{ADA}_{1}{ }^{-}-\mathrm{SCID} \quad(n) \downarrow$} & 1 & -1 & & 24.9 & $(2)$ & $9.24 \pm 3.2$ \\
\hline & 2 & - & & 16.2 & (1) & $4.03 \pm 2.2$ \\
\hline & 3 & $<0.01$ & $(2)$ & 6.2 & $(2)$ & 3.70 \\
\hline & 4 & 0.05 & $(2)$ & 1.3 & (1) & - \\
\hline & 5 & - & & 6.0 & (1) & $9.20 \pm 2.6$ \\
\hline & 6 & - & & - & & $0.95 \pm 0.55$ \\
\hline & 7 & 0.05 & (1) & 19.8 & (1) & - \\
\hline Average & & \multicolumn{2}{|c|}{$0.035 \pm 0.02$} & \multicolumn{2}{|c|}{$12.4 \pm 9.25$} & $5.42 \pm 3.66$ \\
\hline Normals & & \multicolumn{2}{|c|}{$60.9 \pm 21.0(14) \uparrow$} & \multicolumn{2}{|c|}{$665.0 \pm 154.0(14)$} & $1,558.0 \pm 472.0(5)$ ศ \\
\hline
\end{tabular}

RBC-ADA activity for the !Kung tribesman and the $\mathrm{ADA}^{-}$-healthy individual was determined on Hypaque-Ficoll-separated RBC (see text) in order to reduce possible contribution of lymphocyte ADA activity.

Patients are the same as in Table I. Total ADA activity in five ADA ${ }^{-}$-SCID patients' lymphoid line cells: $1=15.5 \pm 4.5 ; 2=4.7 \pm 2.2 ; 3=5.0 ; 5=12.9 \pm 3.8 ; 6=2.7 \pm 1.2$.

$*$ Measured in nanomoles per milligram protein or hemoglobin per hour at $37^{\circ} \mathrm{C}$, inhibitable by $50 \mu \mathrm{M}$ EHNA \pm SD. Total ADA activity of erythrocytes $=0.19$ for ADA $^{-}$-healthy; 0.26 for !Kung and $0.103 \pm 0.02$ (range $=0.08-0.12$ ) for $\mathrm{ADA}^{-}$-SCID.

$\ddagger$ Number of independent determinations on same individual.

$\$$ Activity may be factitiously low because the cells were in transit for almost $1 \mathrm{wk}$ before separation and assay.

"Patient transfused.

I Number of individuals tested.

The existence of substantial ADA activity in peripheral blood lymphocytes and lymphoid line cells (cells actively synthesizing protein) and virtually absent ADA in the nonprotein synthesizing RBC of our patient suggested that he might have an unstable enzyme. We

TABLE III

Deoxyadenosine Deaminating Activity* of Lymphoid Line Cells (Low Substrate)

\begin{tabular}{|c|c|c|c|c|}
\hline & Patient & $\begin{array}{l}\text { Lymphoid } \\
\text { line cells }\end{array}$ & & $\begin{array}{l}\text { Ratio } \\
\text { Ar:dAr }\end{array}$ \\
\hline $\mathrm{ADA}_{1}{ }^{-}$-healthy $(n) \ddagger$ & & $297.0 \pm 63.0$ & (3) & $1.3 \pm 0.1$ \\
\hline $\mathrm{ADA}_{1}{ }^{-}-\mathrm{SCID} \quad(n) \downarrow$ & $\begin{array}{l}1 \\
2 \\
5 \\
6\end{array}$ & $\begin{array}{r}7.7 \\
3.4 \\
10.2 \\
1.4\end{array}$ & $\begin{array}{l}(2) \\
(1) \\
(2) \\
(2)\end{array}$ & $\begin{array}{l}1.1 \\
1.2 \\
1.0 \\
0.6\end{array}$ \\
\hline Average & \multicolumn{3}{|c|}{$5.68 \pm 4.0$} & $1.0 \pm 0.3$ \\
\hline Normals & \multicolumn{3}{|c|}{$1,276.0 \pm 361.0(7) \S$} & $1.3 \pm 0.2$ \\
\hline
\end{tabular}

* Measured in nanomoles per milligram protein per hour at $37^{\circ} \mathrm{C}$.

$\ddagger$ Number of independent determinations on same individual. $\S$ Number of individuals tested. therefore determined EHNA-inhibitable activity in RBC of different ages, separated by centrifugation on arabinogalactan gradients (25). The expected age dependency of the cell fractionation was verified by the progressive decline of pyruvate kinase activity in the gradient fractions (25). ADA in normal RBC essentially showed no age-dependent decrease in activity $\left(t_{1 / 2}\right.$ $=231 \mathrm{~d}$ ) (Fig. 1). Initial determinations of ADA activity in gradient-separated $\mathrm{RBC}$ of an $\mathrm{ADA}^{-}$healthy child revealed a two-component curve of decay with a very short half-life (3.2 d) of the first component (not shown). However, the presence of small but detectable numbers of lymphocytes (containing substantial ADA activity) in the reticulocyte rich fraction could have been responsible for this result. To further reduce lymphocyte contamination we column-purified RBC, lysed them in a buffer in which lymphocytes remained microscopically intact, and assayed the supernate. Determination of ADA activity of such gradient-separated RBC of our ADA ${ }^{-}$healthy child revealed that all fractions contained $<1 \%$ of normal ADA activity (Fig. 1). Fractions rich in reticulocytes exhibited greater EHNA-inhibitable ADA activity than did those containing older $\mathrm{RBC}(0.14 \mathrm{vs} .0 .03 \mathrm{U})$. These results were 


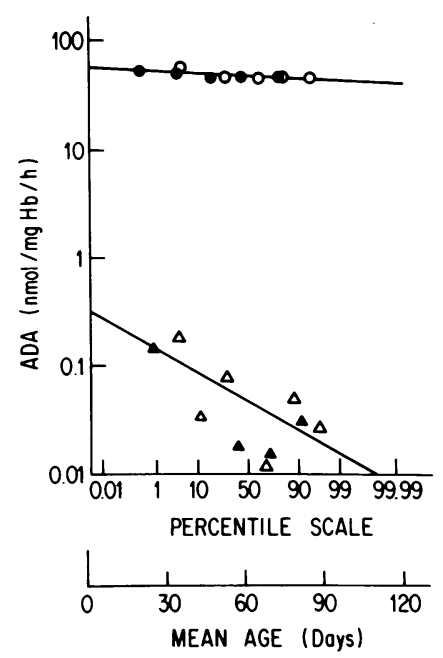

FIGURE 1 ADA activity of RBC separated according to age on an arabinogalactan gradient (25). $O$, Normal; $\triangle$, ADA-deficient healthy child. Solid and open symbols denote two separate experiments (see text for details).

consistent with the existence of an unstable enzyme with a $t_{1 / 2}$ of $22.5 \mathrm{~d}(r=0.751, P=0.0124)$. However, because of the greater difference in enzyme content between RBC and lymphocytes of the patient than that of normals, we could not definitively rule out the possibility that undetected contamination of the upper layers of reticulocytes by small numbers of lymphocytes was responsible for the apparent increased activity in these fractions.

We next determined the stability of the enzyme to heating. ADA of normal lymphoid line cells $\left(\mathrm{ADA}_{1} 1\right.$ phenotype) exhibited a logarithmic decay of enzyme activity at $56^{\circ} \mathrm{C}$ with a $t_{1 / 2}$ of $\cong 50 \mathrm{~min}$, as previously reported for $\mathrm{ADA}_{1} 1$ (13). (Fig. 2). ADA of the patient's lymphoid line cells was very unstable and had lost $50 \%$ of activity in $<10 \mathrm{~min}$. ADA activity of lymphocytes from the !Kung tribesman was also unstable with a $t_{1 / 2}$ of $10 \mathrm{~min}$. Residual EHNA-inhibitable ADA activity of lymphoid line cells from one $\mathrm{ADA}_{1}{ }^{-}$patient (GM 2606) with SCID showed normal stability (Fig. 2). ADA activity of a second patient with $\mathrm{ADA}_{1}{ }^{-}$-SCID (GM 2756) appeared to have intermediate stability with a suggestion of an unstable component and a component with normal stability.

To further characterize the ADA activity in normals, $\mathrm{ADA}_{1}{ }^{-}$-healthy and $\mathrm{ADA}_{1}{ }^{-}$-SCID individuals, lymphoid line extracts were chromatographed on Sephadex G-200. ADA $_{1}$ activity can exist as a low molecular weight ( $\cong 32,000$ daltons) catalytic unit or combined with an enzymatically inactive subunit of $\cong 100,000 \mathrm{~mol}$ wt which has varying degrees of glycosylation (26-30). The several forms of the enzyme thus contain the same catalytic subunit and are inhibitable by EHNA. In contrast, the $\mathrm{ADA}_{2}$ isozyme has been reported as a 100,000 mol wt species and is essentially not inhibitable by EHNA (10). Various tissues and fibroblasts can contain both high and low molecular weight forms of $\mathrm{ADA}_{1}$ $(26,31)$. In contrast, normal LTL, similar to RBC, upon electrophoresis on starch gel and staining, exhibit detectable amounts of only the anodally migrating, low molecular weight form of $\mathrm{ADA}_{1}$. On column chromatography $>97 \%$ of normal lymphoid line ADA eluted with a molecular weight of $\cong 32,000$ (Fig. 3 ). The remainder of the activity was found as a high molecular weight species which was also inhibitable by EHNA. Under these conditions, EHNA noninhibitable activity is not detected in normal lymphoid line cells. ADA of lymphoid line cells derived from our patient also eluted primarily as a $32,000-\mathrm{mol}$ wt species. About $8 \%$ of the activity eluted as a high molecular weight species which was also inhibitable by EHNA. ADA of lymphocytes and lymphoid line cells of the !Kung tribesman also demonstrated a major peak of ADA activity at 32,000 daltons. In contrast, chromatography of enzyme activity from lymphoid line cells of an $\mathrm{ADA}^{-}$-SCID patient (GM 1715), in which $>50 \%$ of ADA activity was not EHNA-inhibitable (Table II), showed only a minor EHNA-inhibitable peak at $32,000 \mathrm{~mol}$ wt with the remainder of the ADA activity eluting as high molecular weight activity ( $>200,000$; not shown) which was essentially not inhibitable by EHNA. This ADA activity could represent a dimer of the $\mathrm{ADA}_{2}$ isozyme described by Schrader (22).

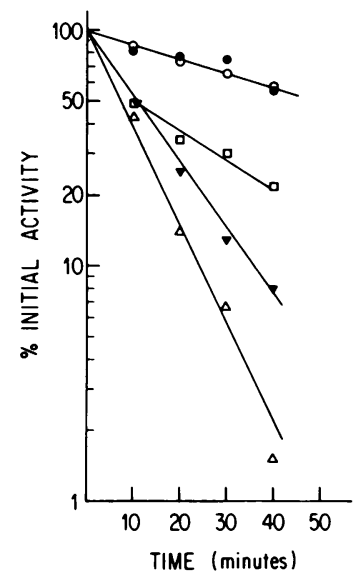

Figure 2 Stability of ADA at $56^{\circ} \mathrm{C}$. Lysates of lymphoid line cells were aliquoted, incubated at $56^{\circ} \mathrm{C}$ for various time intervals, and ADA activity determined (see text for details). $O$, Normal $\mathrm{ADA}_{1} 1 ; \triangle, \mathrm{ADA}^{-}$healthy child; $\Delta, \mathrm{ADA}^{-}-$!Kung tribesman; $\square, \mathrm{ADA}^{-}$-SCID (GM 2756); $9, \mathrm{ADA}^{-}$-SCID (GM 2606). Results of a single representative experiment are shown. Average stability of ADA activity after incubation for $30 \mathrm{~min}$ at $56^{\circ} \mathrm{C}$ was determined in separate independent experiments: normal $=61.5 \pm 8.4(n=4) ; \mathrm{ADA}_{1}{ }^{-}$-healthy $=6.8$ $\pm 4.3(n=4) ; \mathrm{ADA}^{-}-$!Kung $=20.0 \pm 6.6(n=3) ; \mathrm{ADA}_{1}^{-}$-SCID $(\mathrm{GM} 2606)=76.0 \pm 1.7 \quad(n=3) ; \mathrm{ADA}_{1}^{-}$-SCID (GM 2756) $=30.2 \pm 3.0(n=3)$. 
The apparent $K_{\mathrm{m}}$ of ADA in lymphoid line cells of

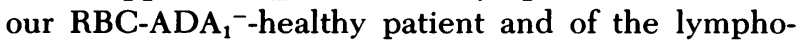
cytes from the !Kung tribesman was like that of ADA in normal lymphocytes, lymphoid line cells, and fibroblasts (30-70 $\mu \mathrm{M})$ (Fig. 4A). In contrast, lymphoid line ADA activity of GM 1715 demonstrated a LineweaverBurk plot with two components, one with a normal $K_{\mathrm{m}}$ and a second component with a $K_{\mathrm{m}}$ that ranged between 350-1,000 $\mu \mathrm{M}$ (Fig. 4B). GM 1715 was also slightly different from the other $\mathrm{ADA}^{-}$-SCID LTL on gel filtration and ratio of activity at high and low substrate (see previous results). However, we have found this second $K_{\mathrm{m}}$, in addition to ADA with a normal $K_{\mathrm{m}}$ in cultured cells from each of the three additional $\mathrm{ADA}_{1}{ }^{-}$-SCID patients we have examined (GM 2578, 2606 , and 2756). The finding of the same abnormality in all four unrelated patients, in light of the prior de-
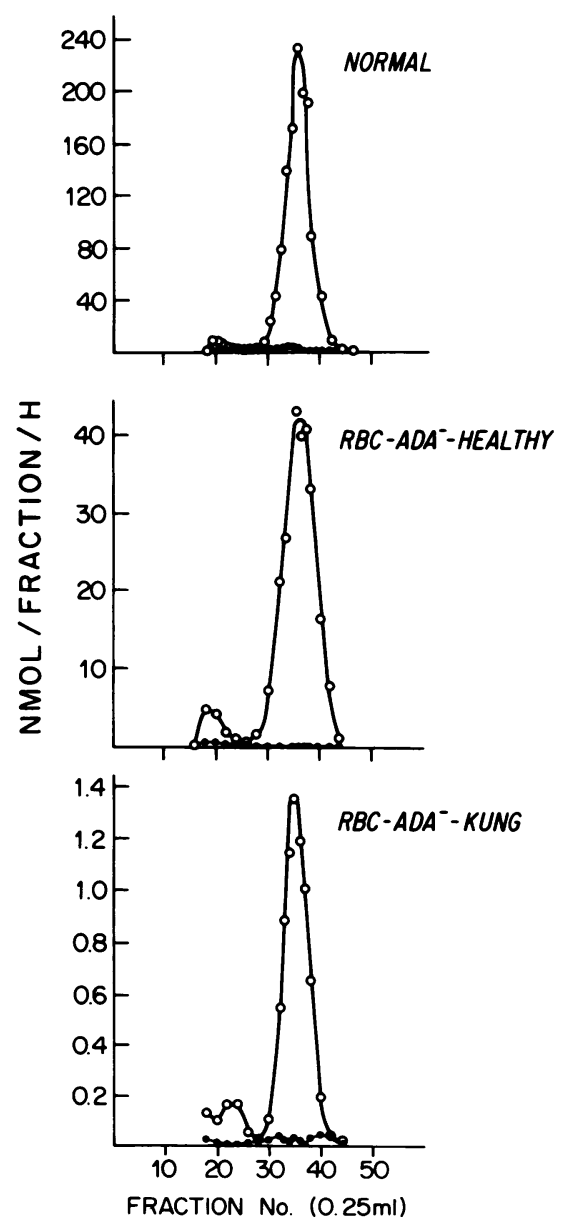

FIGURE 3 Sephadex G-200 gel chromatography of ADA activity of lymphoid line cells. The major peak of ADA activity occurred at an apparent molecular weight of 32,000 and was inhibitable by EHNA in lymphoid line cells from normals, the partially ADA $^{-}$-healthy child, and lymphocytes of the partially ADA ${ }^{-}-$!Kung tribesman (see text for details).
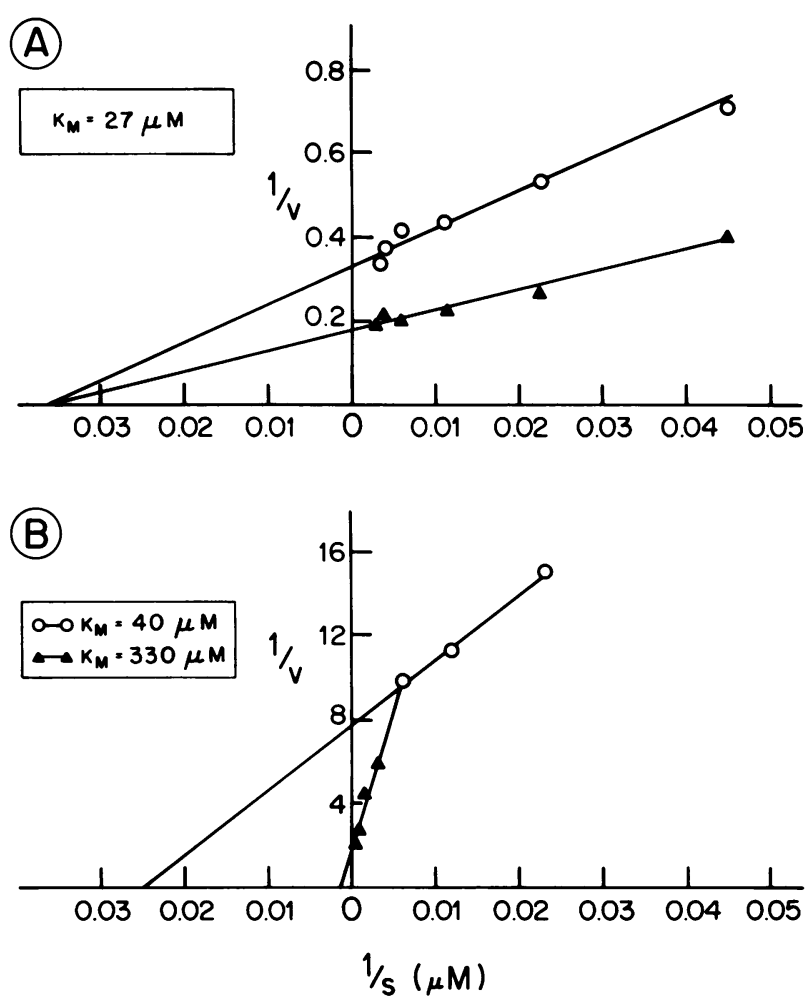

FIGURE $4 K_{m}$ of ADA of lymphoid cells. (A) LineweaverBurk plot of ADA activity in lymphoid cells of two individuals who have marked deficiency of ADA in RBC but only partial deficiency in lymphoid cells. The $K_{m}$ is like that observed in normal lymphoid cells. $\Delta$, !Kung tribesman (GM 3043); $\square$, RBC-ADA ${ }^{-}$healthy child (GM 2294). (B) ADA of lymphoid line cells derived from an $\mathrm{ADA}_{1}^{-}$-SCID patient (GM 1715). The Lineweaver-Burk plot suggests that total residual ADA activity reflects two species of ADA; the $K_{\mathrm{m}}$ of $40 \mu \mathrm{M}$ is like that of the normal $\mathrm{ADA}_{1}$ isozyme (affected in $\mathrm{ADA}^{-}$-SCID), whereas the $K_{\mathrm{m}}$ of $330 \mu \mathrm{M}$ is like that of the normal $\mathrm{ADA}_{2}$ isozyme (10). Over $90 \%$ of the ADA activity determined at high substrate eluted as a non-EHNA inhibitable high molecular weight species, properties which are characteristic of the $\mathrm{ADA}_{2}$ isozyme (not shown). The $K_{\mathrm{m}}$ of $\mathrm{ADA}_{2}$ isozymes is not detected in normal lymphoid cells under these conditions because in normal cells it represents a minor percentage of total ADA activity.

scription of an additional form of $\mathrm{ADA}\left(\mathrm{ADA}_{2}\right)$ with a similar low affinity for substrate, would suggest that this second $K_{\mathrm{m}}$ represents the detection of the low amounts of the normal $\mathrm{ADA}_{2}$ isozyme unmasked by the absence of the major high affinity $\mathrm{ADA}_{1}$. Although highly unlikely, it cannot be ruled out that the double $K_{\mathrm{m}}$ represents the expression of two different mutant alleles for ADA in each of the four patients.

Electrophoretic mobility. The ADA of both our patient and that previously reported (5) of the !Kung tribesman was indistinguishable from that of normal $\mathrm{ADA}_{1}$ of a 1 phenotype.

Metabolites. To assess whether the residual en- 
zyme activity was sufficient to prevent accumulation of metabolites in vivo, we determined dATP in RBC and deoxyadenosine and adenosine in urine. Normal RBC were found to contain $2-4 \mathrm{nmol}$ of $\mathrm{dATP} / \mathrm{ml}$ packed RBC $(2.6 \pm 1.1)$. RBC of two ADA-deficient patients with SCID contained between 400 and 1,000 $\mathrm{nmol} / \mathrm{ml}$ packed $\mathrm{RBC}$, similar to previously reported values $(15,32)$. Our patient's $\mathrm{RBC}$ were originally reported to contain normal amounts of dATP (15). More sensitive determinations revealed slightly, but detectably increased RBC dATP (12.3 nmol/ml packed RBC; normal, 2.6 \pm 1.1 ). He also excreted detectable amounts of deoxyadenosine $(1.1 \mu \mathrm{M})$ but this was $\cong 1 \%$ of that excreted by two $\mathrm{ADA}^{-}$immunodeficient patients (50-100 $\mu \mathrm{M}$ deoxyadenosine; normal, $<0.5 \mu \mathrm{M}$ ). Adenosine excretion of $2.5 \mu \mathrm{M}$ was within the normal range (up to $3.6 \mu \mathrm{M}$ ). RBC from the !Kung tribesman also contained detectable dATP $(6.1 \mathrm{nmol} / \mathrm{ml}$ packed $\mathrm{RBC})$. Urine was not available for examination.

\section{DISCUSSION}

Inherited deficiency of the purine salvage enzyme ADA (EC 3.5.4.4) is responsible for approximately onethird of unselected cases of SCID (including X-linked and autosomal recessive), or almost $50 \%$ of autosomalrecessive $\operatorname{SCID}(2,33)$. As in any rare autosomal-recessive disorder in a heterogeneous population, it can be expected that different cases will represent different mutations at the same locus as part of an allelic series (34). In a nonconsanguineous family, a given affected individual may even be a "compound heterozygote" carrying too different "deficiency" alleles. Evidence for some degree of genetic heterogeneity has been provided by the demonstration of both cross reacting material positive and cross reacting material negative patients (35). In addition, aberrations in electrophoretic mobility and heat stability have been found $(36,37)$. Perhaps the clearest example of genetic heterogeneity in this disorder has been the description of an immunologically normal !Kung tribesman who has virtually absent ADA activity in RBC but $20 \%$ of normal activity in lymphocytes (5).

We have studied ADA activity in various cells of a second individual who was detected by virtue of absent RBC ADA during New York State-mandated screening of newborns. This black child is immunologically normal and healthy at $2.5 \mathrm{yr}$ of age (7). He has RBC-ADA activity not detectably different from that of $\mathrm{RBC}$ of $\mathrm{ADA}^{-}$individuals with SCID both at high and low substrate concentrations.

Initially, mononuclear cell ADA activity was determined under conditions which could measure activity of the $\mathrm{ADA}_{2}$ isozyme in addition to the activity of $\mathrm{ADA}_{1}$, which is deficient in $\mathrm{ADA}_{\mathbf{1}}^{-}$-SCID. Under these conditions, our patient's mononuclear cells contained de- tectably but not strikingly greater ADA activity than did mononuclear cells from patients with $\mathrm{ADA}_{1}{ }^{-}$SCID. In contrast, when assayed under conditions more specific for measurement of the major human form of $\mathrm{ADA}\left(\mathrm{ADA}_{1}\right)$, mononuclear cells from $\mathrm{ADA}_{1}^{-}-\mathrm{SCID}$ patients contained very little residual activity (average $=2 \%$ of normal) although mononuclear cells of our ADA $_{1}^{-}$healthy patient still exhibited substantial activity ( $24 \%$ of normal). The !Kung tribesman has previously been reported to have $20 \%$ of normal lymphocyte ADA activity (5). The values reported here for ADA activity of lymphocytes from the !Kung tribesman, although higher than mononuclear cell ADA of $\mathrm{ADA}_{1}^{-}$ SCID, are relatively lower than previously reported. However, the values for the !Kung cells may be factitiously low as both the lymphocytes and RBC were isolated from whole blood in ACD solution which had been in transit for over $4 \mathrm{~d}$ and arrived at room temperature.

LTL line cells from both our patient and the !Kung tribesman also exhibited substantial ADA activity, in contrast to lymphoid line cells from patients with $\mathrm{ADA}^{-}$-SCID. Lymphoid line cells derived from the !Kung tribesman exhibited activity similar to lymphoid lines from obligate heterozygotes for ADA deficiency and individual values overlapped with those of normal lymphoid line cells. ADA activity in lymphoid line cells from our patient showed marked variation. We have previously reported that ADA activity of normal and deficient fibroblasts shows significant (approximately twofold) variation with differing growth conditions (31). Such alterations may also occur in lymphoid line cells and be magnified by the presence of an unstable enzyme.

ADA activity in lymphoid cells of both the !Kung tribesman and our patient was markedly less stable in vitro than normal. Because both may share a common racial background, it is tempting to speculate that they carry the same mutations. In addition, an $\mathrm{ADA}^{-}-\mathrm{SCID}$ patient whose lymphoid line ADA suggested a twocomponent heat stability shares the same ethnic background as does the !Kung, our patient, and another patient whose ADA was reported to be less stable when exposed to heat (26). Determination of the amino acid and base substitutions involved will be required to determine whether these patients do indeed carry the same mutation.

We have also attempted to examine in vivo stability of the ADA by determining activity in RBC of different ages. The results are compatible with a diminished half-life of ADA in vivo. However, because the ratio of activity in lymphocytes to that in $\mathrm{RBC}$ is $\cong 100: 1$ in the patient (but only about 10:1 in normals), any preferential contamination of the reticulocyte-rich layers by lymphocytes could give the appearance of an agerelated decrease of the patient's ADA activity. There- 
fore, despite the precautions taken to eliminate such lymphocyte contamination, complete confirmation of the in vivo instability would require sensitive histochemical techniques to identify reticulocytes as the cells containing greater ADA activity. More important, the observed rate of decline in ADA activity in RBC extrapolates to $\cong 1 \%$ of normal RBC activity in the patient's reticulocytes. Therefore, unless ADA synthesis is "turned off" before the reticulocyte stage, the degree of in vivo instability alone cannot account for the amount of enzyme activity observed in lymphocytes. It is possible that this offspring of unrelated parents carries two different deficiency alleles for $\mathrm{ADA}_{1}$. Unfortunately, neither parent is currently available for further study.

Whatever the mechanism, it is clear that in vivo there is sufficient ADA in tissues other than RBC of this patient to prevent marked accumulations of either dATP in RBC, ATP, or cyclic AMP in lymphocytes $(7)^{2}$ or marked excretion of deoxyadenosine in urine. Looking at the finding in a reverse fashion, excretion of up to $0.48 \mu \mathrm{mol}$ deoxyadenosine $/ \mathrm{d}$ and $12 \mathrm{nmol} / \mathrm{ml} \mathrm{RBC}$ dATP is compatible with normal immune function.

\section{ACKNOWLEDGMENTS}

We would like to thank Drs. R. Hong, S. Polmar, A. Rubinstein, J. Lightbody, C. Griscelli, and P. Papageorgiou for generously providing RBCs, lymphocytes and urine for determination of metabolites and/or ADA activity and/or for cooperating with the National Institutes of Health Human Genetic Mutant Cell Repository in establishing cell lines from some of these patients.

The encouragement and patient advice of Dr. P. Brown was invaluable for the success of the determinations using high-pressure liquid chromatography.

This work was supported by grants AI 10343 and AMO 9274 from the National Institutes of Health and grant 6-4 from the National Foundation-March of Dimes.

\section{REFERENCES}

1. Giblett, E. R., J. E. Anderson, F. Cohen, B. Pollara, and H. J. Meuwissen, 1972. Adenosine-deaminase deficiency in two patients with severely impaired cellular immunity. Lancet. II: 1067-1069.

2. Meuwissen, H. J., R. J. Pickering, B. Pollara, and I. H. Porter, editors. 1975. Combined Immunodeficiency Disease and Adenosine Deaminase Deficiency. A Molecular Defect. Academic Press, Inc., New York.

3. Hirschhorn, R. 1977. Defects of purine metabolism in immunodeficiency diseases. In Progress in Clinical Immunology. R. S. Schwartz, editor. Grune \& Stratton, Inc., New York 3: 67-83.

4. Jenkins, T. 1973. Red blood cell adenosine deaminase deficiency in a "healthy" !Kung individual. Lancet II: 736.

5. Jenkins, T., A. R. Rabson, G. T. Nurse, A. B. Lane, and D. A. Hopkinson. 1976. Deficiency of adenosine deaminase not associated with severe combined immunodeficiency. J. Pediatr. 89: 732-736.

6. Harris, H. 1970. The Principles of Human Biochemical
Genetics. North-Holland Publishing Company, Amsterdam.

7. Borkowsky, W., A. A. Gershon, and R. Hirschhorn. 1978. Adenosine deaminase deficiency without immunodeficiency. Pediatr. Res. 12: 478.

8. Hirschhorn, R., N. Beratis, F. S. Rosen, R. Parkman, R. Stern, and S. Polmar. 1975. Adenosine-deaminase deficiency in a child diagnosed prenatally. Lancet. I: 73-79.

9. Hopkinson, D. A., P. J. L. Cook, and H. Harris. 1969. Further data on the adenosine deaminase (ADA) polymorphism and a report of a new phenotype. Ann. Hum. Genet. 32: 361-367.

10. Schrader, W. P., B. Pollara, and H. J. Meuwissen. 1978. Characterization of the residual adenosine deaminating activity in the spleen of a patient with combined immunodeficiency disease and adenosine deaminase deficiency. Proc. Natl. Acad. Sci. U. S. A. 75: 446-450.

11. Coleman, M. S., and J. J. Hutton. 1975. Micromethod for quantitation of adenosine deaminase activity in cells from human peripheral blood. Biochem. Med. 13: 46-55.

12. Spencer, N., D. A. Hopkinson, and H. Harris. 1968. Adenosine deaminase polymorphism in man. Ann. Hum. Genet. 32: 9-14.

13. Osbourne, W. R. A., and N. Spencer. 1973. Partial purification and properties of the common inherited forms of adenosine deaminase from human erythrocytes. Biochem. J. 133: 117-123.

14. Osbourne, W. R. A., S-H. Chen, and C. R. Scott. 1978. Use of the integrated steady-state rate equation to investigate product inhibition of human red cell adenosine deaminase and its relevance to immune dysfunction. J. Biol. Chem. 253: 323-325.

15. Cohen, A., R. Hirschhorn, S. D. Horowitz, A. Rubinstein, S. H. Polmar, R. Hong, and D. W. Martin, Jr. 1978. Deoxyadenosine triphosphate as a potentially toxic metabolite in adenosine deaminase deficiency. Proc. Natl. Acad. Sci. U. S. A. 75: $472-476$.

16. Rubinstein, A., R. Hirschhorn, M. Sicklick, and R. A. Murphy. 1979. In vivo and in vitro effects of thymosin and adenosine deaminase on adenosine deaminase deficient lymphocytes. N. Engl. J. Med. 300: 387-392.

17. Polmar, S. H., R. C. Stern, A. L. Schwartz, E. M. Wetzler, P. A. Chase, and R. Hirschhorn. 1976. Enzyme replacement therapy for adenosine deaminase deficiency and severe combined immunodeficiency. N. Engl.J. Med. 295: $1337-1343$.

18. Jenkins, T., A. B. Lane, G. T. Nurse, and D. A. Hopkinson. 1979. Red cell adenosine deaminase (ADA) polymorphism in Southern Africa, with special reference to ADA deficiency among the !Kung. Ann. Hum. Genet. 42: 425-433.

19. Uberti, J., J. J. Lightbody, J. W. Wolf, J. A. Anderson, R. H. Reid, and R. M. Johnson. 1978. The effect of adenosine on mitogenesis of ADA-deficient lymphocytes. Clin. Immunol. Immunopathol. 10: 446-458.

20. Carson, D. A., J. Kaye, J. E. Seegmiller. 1977. Lymphospecific toxicity in adenosine deaminase deficiency and purine nucleoside phosphorylase deficiency: possible role of nucleoside kinases. Proc. Natl. Acad. Sci. U. S. A. 74: $5677-5681$.

21. Solter, A. W., and R. E. Handschumacher. 1969. A rapid quantitative determination of deoxyribonucleoside triphosphates based on the enzymatic synthesis of DNA. Biochim. Biophys. Acta. 174: 585-590.

22. Kuttesch, J. F., F. C. Schmalstieg, and J. A. Nelson. 1978. Analysis of adenosine and other adenine compounds in patients with immunodeficiency diseases. J. Liquid Chromatog. 1: 97-109. 
23. Krstulovic, A. M., P. R. Brown, and D. M. Rosie. 1977. Identification of nucleosides and bases in serum and plasma samples by reverse-phase high performance liquid chromatography. Anal. Chem. 29: 2237-2241.

24. Beutler, E., C. West, and K-G. Blume. 1976. The removal of leukocytes and platelets from whole blood. J. Lab. Clin. Med. 88: 329-333.

25. Corash, L. M., S. Piomelli, H-C. Chen, C. Seaman, and E. Gross. 1974. Separation of erythrocytes according to age on a simplified density gradient. J. Lab. Clin. Med. 84: $147-151$.

26. Edwards, Y. H., D. A. Hopkinson, and H. Harris. 1971. Adenosine deaminase isozymes in human tissues. Ann. Hum. Genet. 35: 207-219.

27. Hirschhorn, R. 1975. Conversion of human erythrocyteadenosine deaminase activity to different tissue-specific isozymes: evidence for a common catalytic unit. J. Clin. Invest. 55: 661-667.

28. Swallow, D. M., L. Evans, and D. A. Hopkinson. 1977. Several of the adenosine deaminase isozymes are glycoproteins. Nature (Lond.). 269: 261-262.

29. Schrader, W. P., and A. R. Stacy. 1977. Purification and subunit structure of adenosine deaminase from human kidney. J. Biol. Chem. 252: 6409-6415.

30. Daddona, P. E., and W. N. Kelley. 1978. Human adenosine deaminase binding protein. Assay, purification, and properties. J. Biol. Chem. 253: 4617-4623.

31. Hirschhorn, R., N. G. Beratis, and F. Martiniuk. 1978. Adenosine deaminase. Alterations in activity and iso- zymes during growth of normal and genetically deficient fibroblasts. Exp. Cell Res. 117: 103-109.

32. Coleman, M. S., J. Donofrio, J. J. Hutton, L. Hahn, A. Daoud, B. Lampkin, and J. Dyminski. 1978. Identification and quantitation of adenine deoxynucleotides in erythrocytes of a patient with adenosine deaminase deficiency and severe combined immunodeficiency. J. Biol. Chem. 253: 1619-1626.

33. Hirschhorn, R., G. F. Vawter, J. A. Kirkpatrick, Jr. and F. S. Rosen. 1979. Adenosine deaminase deficiency: frequency and comparative pathology in autosomally recessive severe combined immunodeficiency. Clin. Immunol. Immunopathol. In press.

34. McKusick, V. A. 1973. Phenotypic diversity of human diseases resulting from an allelic series. Am. J. Hum. Genet. 25: 446.

35. Carson, D. A., R. Goldblum, and J. E. Seegmiller. 1977. Quantitative immunoassay of adenosine deaminase in combined immunodeficiency disease. J. Immunol. 118: 270-273.

36. Hirschhorn, R., N. Beratis, and F. S. Rosen. 1976. Characterization of residual enzyme activity in fibroblasts from patients with adenosine deaminase deficiency and combined immunodeficiency: evidence for a mutant enzyme. Proc. Natl. Acad. Sci. U. S. A. 73: 213-217.

37. Chen, S-H., C. R. Scott, and K. R. Swedberg. 1975. Heterogeneity for adenosine deaminase deficiency: expression of the enzyme in cultured skin fibroblasts and amniotic fluid cells. Am. J. Hum. Genet. 27: 46-52. 